\title{
Experimental Pharmacological Inquiries into a New Anti-Nicotine and Anti-Morphine Drug " TERPIDAN"
}

\author{
by \\ Mikio SATO, ${ }^{*}$ Toyoyuki TAMURA, ${ }^{*}$ Shigeru KATO* \\ and Kotobuki MITSUI*
}

\section{Introductory}

Of late the toxicity of nicotine has come to receive attention from many quarters and this is especially important as it has possible relations with the carcinogenetic properties of cigarette. U.S. Cancer Research Institute and our National Preventive Hygiene Institute have published valuable contributions to this subject. On the other hand, though the toxicity of morphine has been long studied we have not had to date a report of decisive importance.

Of many disturbances caused by the entry of nicotine into the vital body, what $\mathrm{s}$ prominent is an excitation of both the sympathetic and parasympathetic nervous systems through its action upon the autonomous nervous ganglions. For this reason, a drug possessing anti-nicotine properties must act inhibitorily upon the rise in blood pressure and respiratory frequency. Generally speaking, when a matter of alkaloid or heavy metal base is orally administered, activated carbon, tannic acid or magnesium oxide among others are used as antidotes. They possess such actions as composition, adsorption, or vomitting, thus removing them outside the body in the harmless fashion. Among the anti-nicotine agents developed in recent years, there are mentioned sodium glucuronate, DL-methionin, vitamin $\mathrm{C}$, vitamin $\mathrm{B}$, thio-sulphuric sodium, glucose, etc. But they are far from being ideal drugs for the specified purposes.

The authors have recently developed a new anti-nicotine agent and named it TERPIDAN. It is basically prepared from glucose and resins in the certain process, and being in the powdered state, this TERPIDAN is black brown and has a particular odor.

The virtues of TERPIDAN are not of single action but various virtues of combination, adsorption and anti-toxicity are thought to work together in the potential manner. As the chief effective ingredient is soluble in water, it is not easy to be directly transferred into an organic catalyzer. The use of such alkaloid coloring reagents as Fröhde reagent, Erdomann reagent and Mandelin reagent (prepared by the National Hygiene Laboratory) has established the fact that no alkaloid has been detected within these limits. In the present study nicotine specimen used was the pure nicotine which was offered through courtesy of Japan Monopoly Corporation.

* 佐藤 三樹雄，时村 豊幸，加藤 茂，三井 寿：Dept. of Pharmacology, Nihon Univ. School of Dentistry (Director: Prof. Mikio SATO) 


\section{Procedures and Materials}

A. Toxicity of TERPIDAN upon Mice

As a material for this purpose, TERPIDAN was emulsified by means of gum Arabic and prepared into solutions of varying concentrations. Five groupings of mice, each containing ten (10), with the average weight of 15 grams were employed and $0.3 \mathrm{cc}$ of TERPIDAN was administered through the mouth.

\section{TABLE 1}

\begin{tabular}{c|c}
\hline $\begin{array}{c}\text { Administered quantity } \\
\mathrm{g} / \mathrm{kg}\end{array}$ & $\begin{array}{c}\text { Rate of survival after } \\
24 \text { hours }\end{array}$ \\
\hline 0.8 & 100 \\
1.0 & 100 \\
1.2 & 80 \\
1.7 & 50 \\
2.1 & 20
\end{tabular}

In terms of the average weight of an adult man $(60 \mathrm{~kg})$, the experimental quantity corresponds to about 100 grams which are 300 tablets in the standard tablet contents of 0.3 grams. Therefore, in the ordinary application of TERPIDAN we believe that there is no concern about its toxicity at all.

\section{B. Toxicity of Domestic Cigarettes}

The extracted fluid of cigarettes was subcutaneously injected in the amont of $33.3 \mathrm{mg} / \mathrm{Kg}$ into mice of $15 \mathrm{~g}$ regardless of sex and measurements were taken on their lengths of survival. For the preparation of cigarette extracts, $0.8 \mathrm{~g}$ of powdered cigarettes of various brands was mixed with $80 \mathrm{cc}$ physiological salt solution.

The result of the test under this heading may be summarized as follows.

Gigarette brands Average time of death

IKOI
MOMOYAMA
BATS
HIKARI
PEARLS
SHINSEI
PEACES
KIKYO
FUJI

NIKKO
$12 \mathrm{~min}$.

$14 \mathrm{~min}$.

$17 \mathrm{~min}$.

$30 \mathrm{sec}$.

19 min. 25 sec.

$24 \mathrm{~min}$.

$34 \mathrm{~min} .30 \mathrm{sec}$.

$36 \mathrm{~min}$. $50 \mathrm{sec}$.

$39 \mathrm{~min}$.

$39 \mathrm{~min} .45 \mathrm{sec}$.
Percentage of death after 24 hours

$$
\begin{array}{r}
100 \% \\
100 \% \\
70 \% \\
60 \% \\
80 \% \\
80 \% \\
60 \% \\
50 \% \\
50 \% \\
40 \%
\end{array}
$$


These figures are graphically presented as follows.

Fig. 1

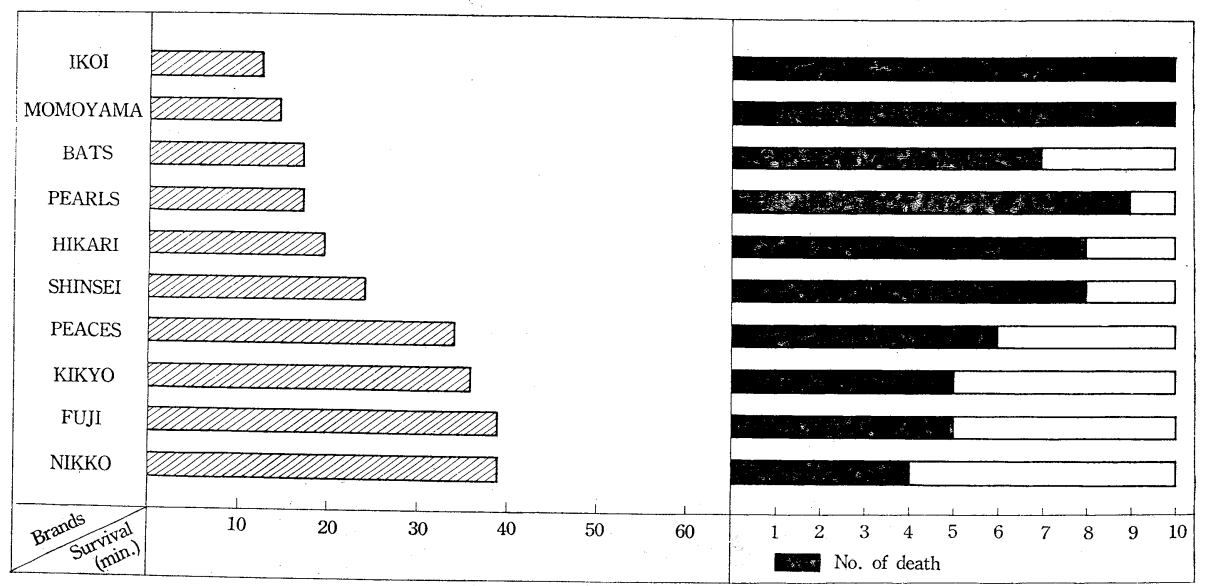

Of various brands, IKOI is found to be the most potent with the average time of death being 12.3 minutes and NIKKO to be the weakest with the average time of death being 39.4 minutes. The conclusion is that the longer the time of survival is, the less is the rate of death.

\section{Actions of TERPIDAN upon Respiration and Blood Pressure}

The experimental rabbits were narcotized by means of urethane and after the neck region was cut open, the tambour and mercury hemodynamometer were connected with trachea and arteria carotis communis and the respiration and blood pressure were recorded on the kymographion.

TERPIDAN was mixed with the physiological salt solution and what was soluble has been used for intravenous purposes (Fig. 2).

\section{Actions of Nicotine upon Respiration and Blood Pressure}

The experimental animals have been treated in the same manner as C) above. Pure nicotine was diluted with the physiological salt solution and it was intravenously injected into the auricular region.

With an injection of $1 \mathrm{mg} / \mathrm{kg}$, a temporary decrease by $25 \mathrm{~mm}$ took place in the blood pressure for an hour. Afterward it went on the increase recording as high as $20 \mathrm{~mm}$. The respiration registered stronger frequency in prallel to the decrease in blood pressure and the tendency was reversed with the increase. With $4 \mathrm{mg} / \mathrm{kg}$, a temporary decrease registered $60 \mathrm{~mm}$ and later it was replaced with an increase with the highest record at $60 \mathrm{~mm}$, this state continuing for about 10 minutes. The respiratory movement was quite in parallel to decrease and increase in blood pressure, and after seven minutes it became weak and stayed in that state for some time.

With $6 \mathrm{mg} / \mathrm{kg}$, the blood pressure registered null simultaneously with the injection and the respiratory movement became larger temporarily. However, after they breathed in the jerky manner for several times they met with death (Fig. 3).

These observations give forth a conclusion that in the injection of nicotine a rise in 
Fig. 2
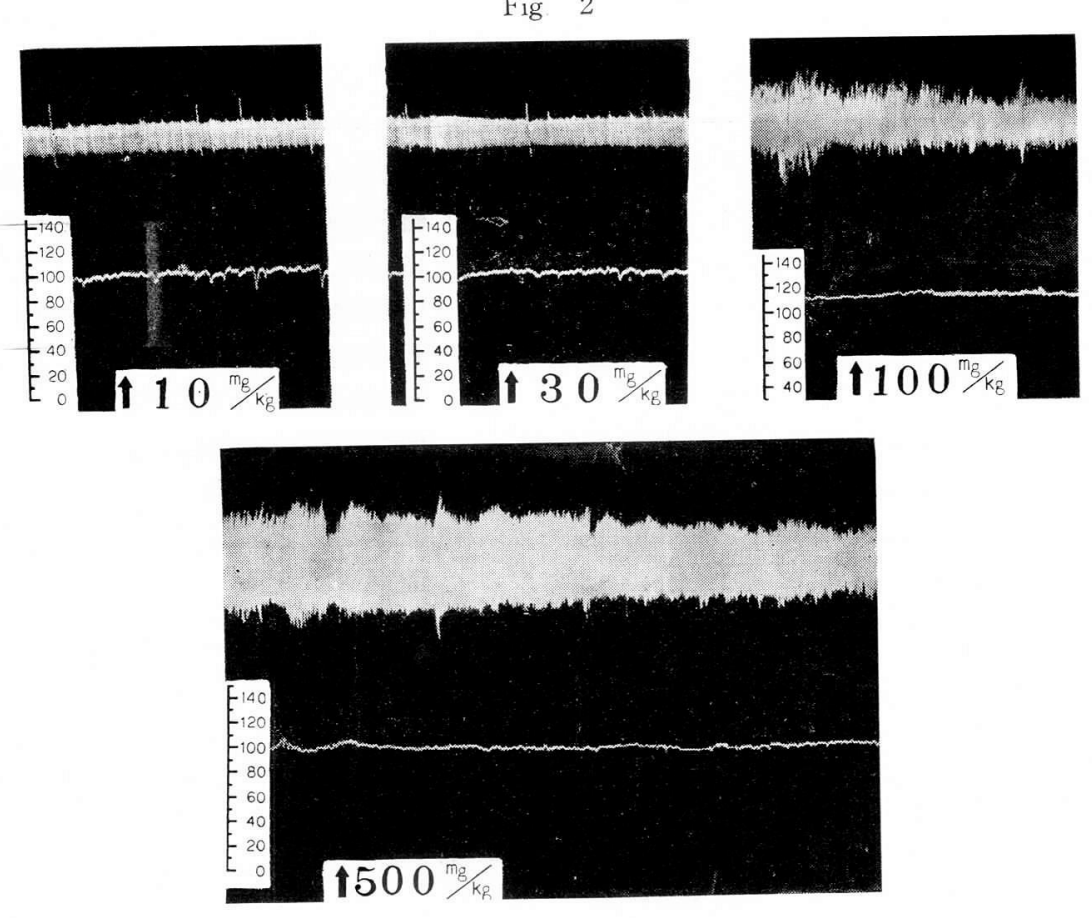

Fig. 3
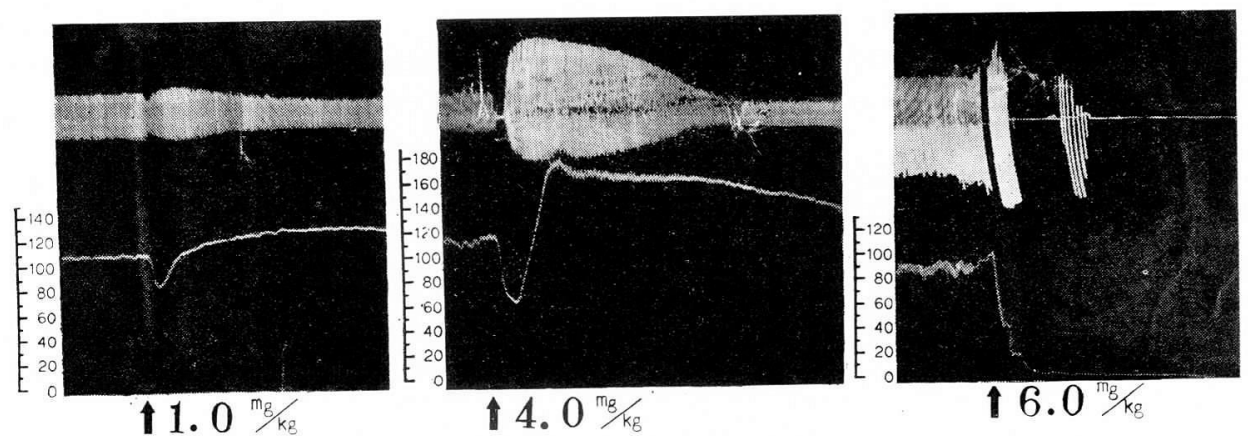

blood pressure is accompanied with stronger trequency in the respiratory movement and a decrease with weaker frequency. This somewhat differs from the action of adrenalin where the respiratory movement is inhibited by a rise in the blood pressure and the tendency is reversed with a decrease in pressure (Fig. 4).

E. Relationship between Nicotine and TERPIDAN upon Ophthal Blood Pressure and Pulse Frequency

The electrocardiograph used was an electric intracerebrohemodynamometer (MPR$30-\mathrm{V}$ Type) with some modifications. Modifications were that the cap attachment was removed and in adjusting to the filter $2-10$ it was rendered so that the needle for ophthalohemodynamometer would act at the height of $1 \mathrm{my}=10 \mathrm{~mm}$. By this means, after 
Fig. 4

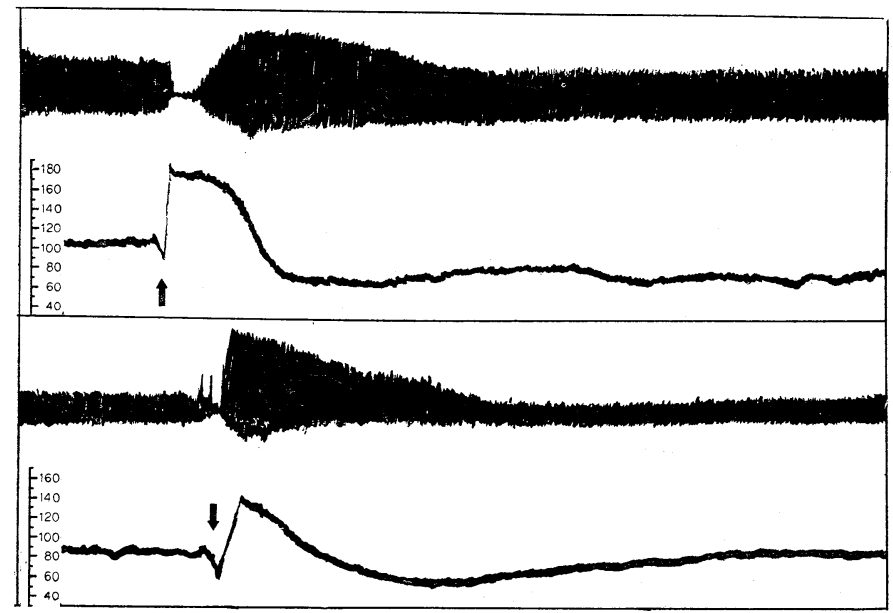

the cap was restored it was possible for the filter 4-10 to detect the ophthal pressure. Although changes were made in the filters, no influence was exerted on the normal sensitivity and therefore, the ophthal pressure could be computed in the right proportion.

The electrocardiograph was operated at the secondary induction and its needle was set at the height of $15 \mathrm{~mm}$.

The experimental rabbits, after they had been narcotized by urethane, were fed with varying amounts of TERPIDAN and at intervals of thirty minutes, one hour and one hour and half after the administration measurements were taken on electrocardiographs and ophthal pressures respectively. Thus a comparison was struck between a group of TERPIDAN-treated rabbits (to the maximum harmless extent) to which LD 100 nicotine was injected and another group of non-treated rabbits to which only LD 100 nicotine was injected.

As a result of the experiment under this section, $1000 \mathrm{mg} / \mathrm{kg}$ of TERPIDAN has been found to be free of any ill effects with other two dosages of $250 \mathrm{mg} / \mathrm{kg}$ and $500 \mathrm{mg} / \mathrm{kg}$ being used. When a diluted solution of pure nicotine was intravenously injected into the auricular region of the rabbits, the restoration of electrocardiographs and ophthal pressures wase retarded in proportion to the amount of nicotine administered. At the level of $5 \mathrm{mg} / \mathrm{kg}$, nearly the half died and at $6 \mathrm{mg} / \mathrm{kg}$ almost all the animals succumbed to death.

On the other hand, with reference to the rabbits which were previously treated with TERPIDAN of $1000 \mathrm{mg} / \mathrm{kg}$ an injection of $6 \mathrm{mg} / \mathrm{kg}$ (LD 100) pure nicotine into the auricular vein after half an hour did not exert any appreciable changes in their electrocardiographs and ophthal pressures. Being on the road to recovery proportionally to the passage of time, they came to a complete recovery after 40 or 45 minutes onward. (Fig. 5)

The control animals of non-treatment immediately showed very high confusions in their electrocardiographs and ophthal pressures when $6 \mathrm{mg} / \mathrm{kg}$ pure nicotine was injected into the auricular vein. Although they gained a temporary recovery after sixty seconds, the pulse frequency gradually became lax and in twenty or thirty minutes all the 
Fig. 5

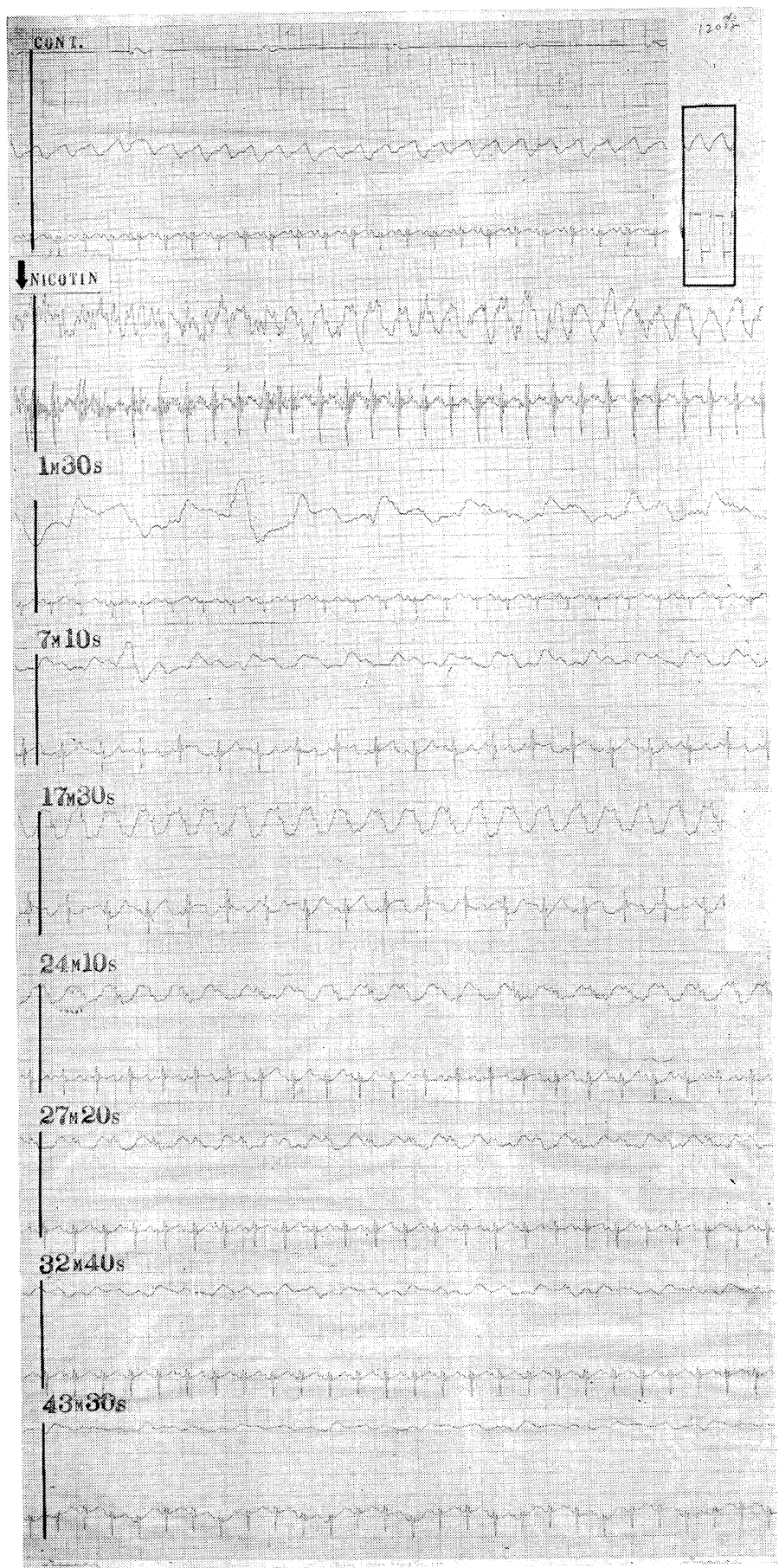


Fig. 6

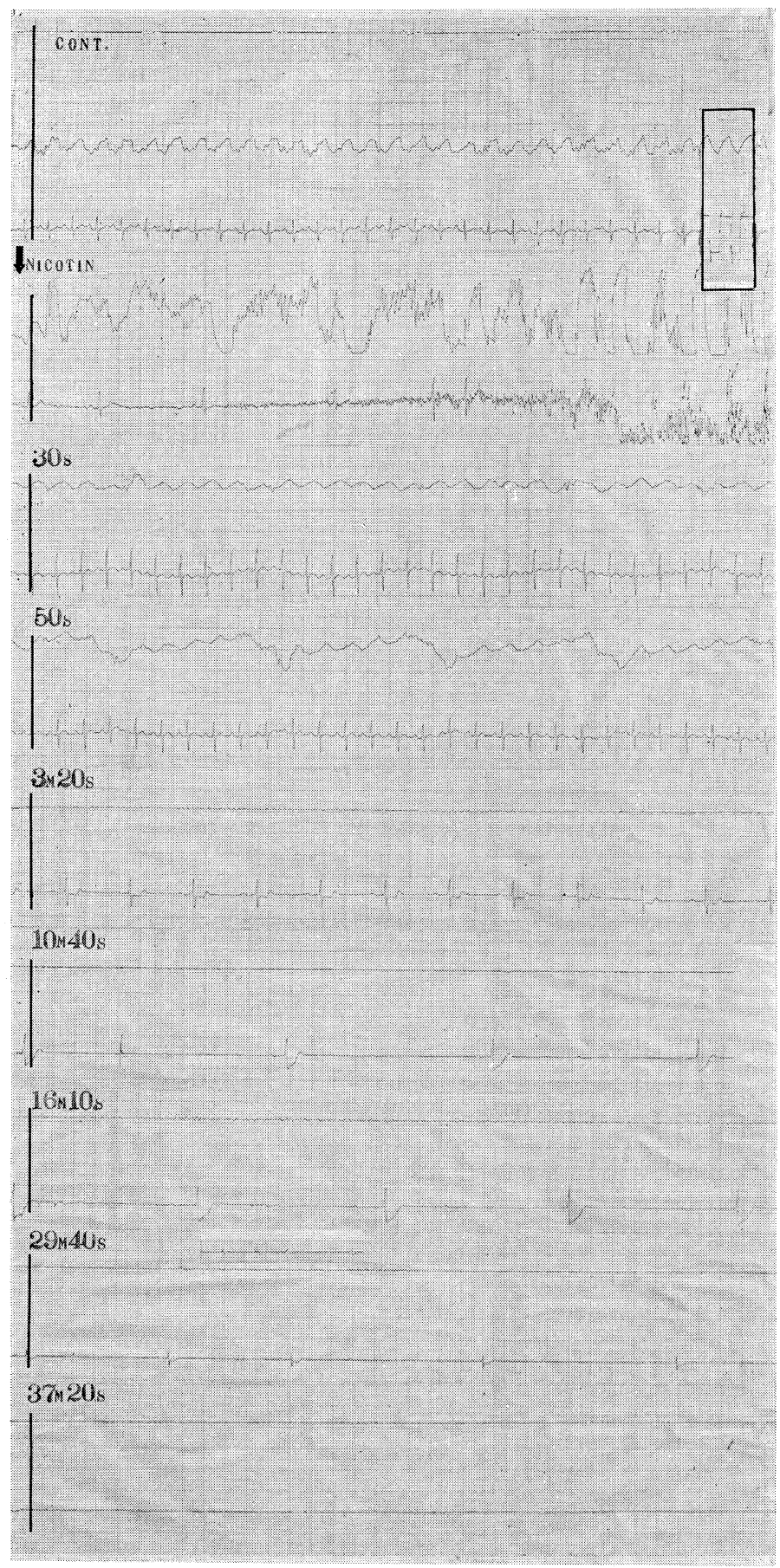


animals succumbed to death (Fig. 6).

The following table gives a tabulation of the pulse frequencies in a definite length of time.

TABLE 2

\begin{tabular}{lc|c|c|c|cc|c|c|c|c|c}
\hline \hline Time (min.) & Control & 1 & 2 & 3 & 10 & 15 & 20 & 25 & 30 & 35 & 40 \\
\hline $\begin{array}{l}\text { Nicotine } 6 \mathrm{mg} / \mathrm{kg} \\
\begin{array}{c}\text { TER. } 1000 \mathrm{mg} / \mathrm{kg} \\
\text { Nicot. } 6 \mathrm{mg} / \mathrm{kg}\end{array}\end{array}$ & 26 & 28 & 18 & 12 & 4 & 4 & 4 & 4 & 2 & 0 & - \\
\hline
\end{tabular}

Fig. 7

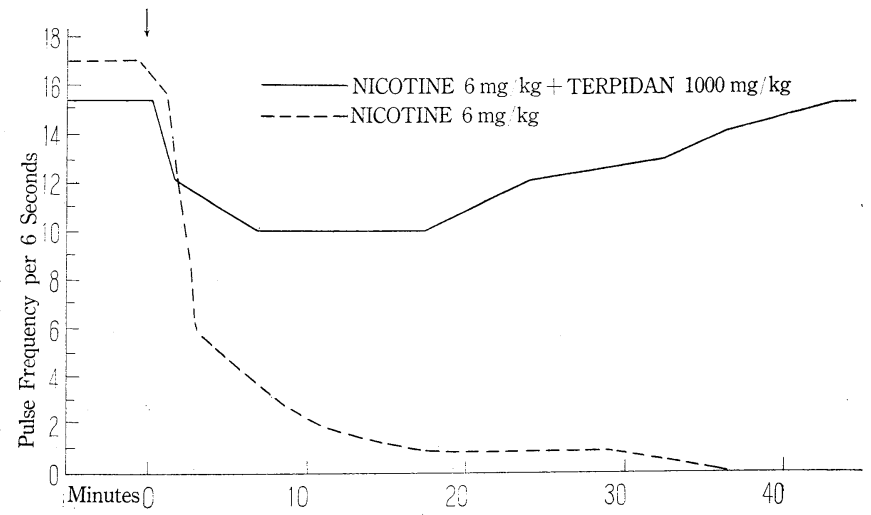

\section{F. Relationship between TERPIDAN and Nicotine upon Respiration and Blood} Pressure

The same experimental procedure was followed as in the previous case and the physiological salt solution of TERPIDAN was injected into the auricular vein. It was already established that the maximum harmless quantity of TERPIDAN for rabbits was $1000 \mathrm{mg} / \mathrm{kg}$. Therefore, one group of animals was premedicated with $1000 \mathrm{mg} / \mathrm{kg}$ TERPIDAN and to this and to another was given an intravenous injection of $6.5 \mathrm{mg} / \mathrm{kg}$ nicotine. Measurements were subsequently taken on the changes in the respiratory movement and blood pressure regarding both groups.

With reference to the TERPIDAN-treated group, blocd pressure went down to $45 \mathrm{~mm}$ immediately after the injection to be replaced by an increase of $40 \mathrm{~mm}$ afterward. When it had registered the highest decrease at $65 \mathrm{~mm}$, it went up again and reached the normal level in 35 minutes. The respiratory showed a wide diffusion of frequency following the injection, registering a tendency as wide as 6 to 7 times. Having continued in this state for some fifteen minutes, it reached back the normalcy in 30 minutes. In E.C.G., the lengthening of $\mathrm{PQ}$ and ST, the downgrade movement and separation of $\mathrm{T}$ were particularly noticed (Figs. 8 and 9 ).

Regarding control, blood pressure went down to $65 \mathrm{~mm}$ immediately following the injection to be replaced by an increase of $60 \mathrm{~mm}$. Immediately afterward it went down 
Fig. 8
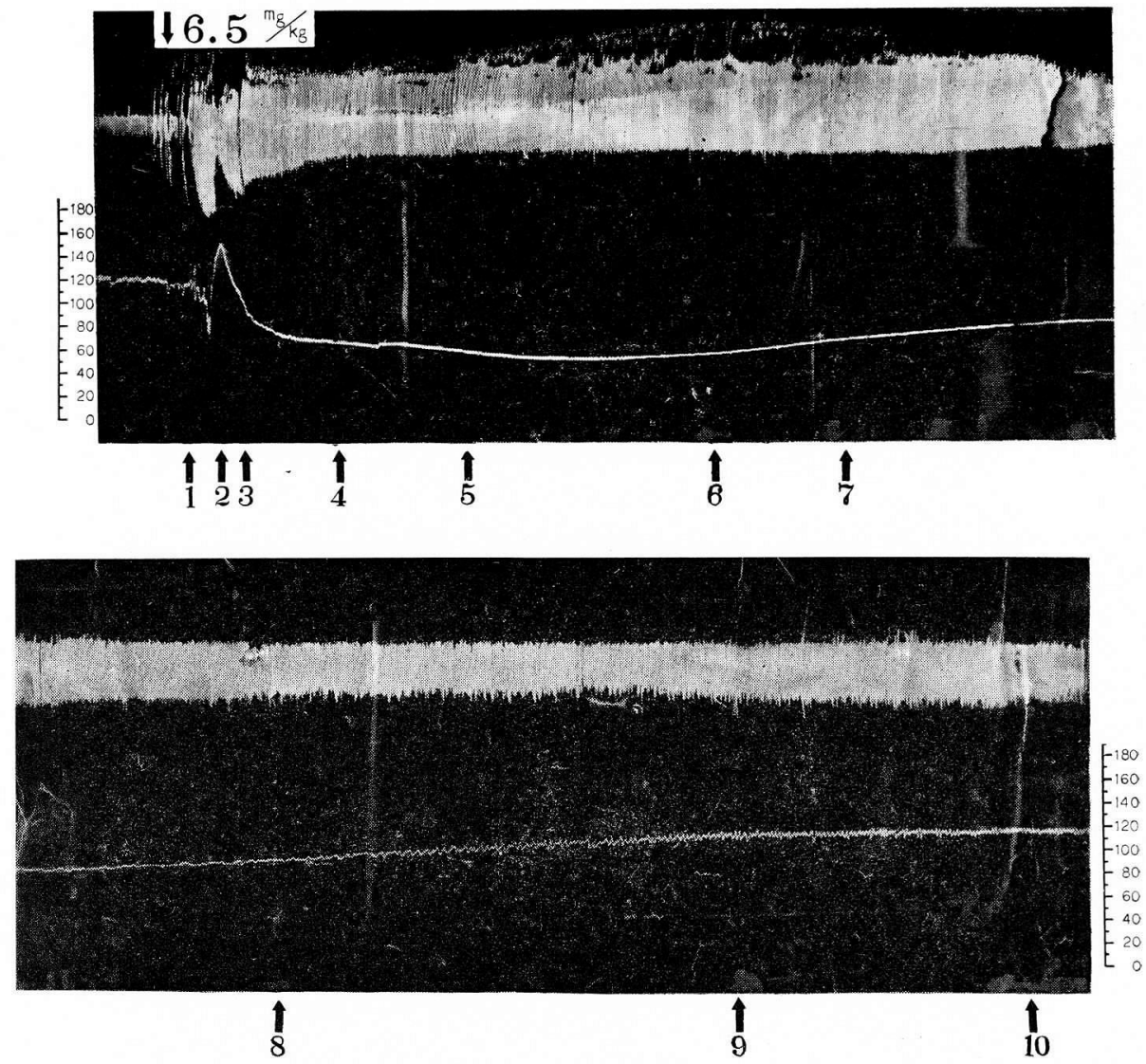

again reaching the point of zero. A transitory enlargement of the respiratory movement took place but it was immediately restored. In E.C.G., the lengthening of ST and upgrade movement of $\mathrm{T}$ were observed in the initial stage and later the lengthening of ST and upgrade movement of $\mathrm{R}$ and $\mathrm{T}$ prevailed (Figs. 10 and 11).

The electrocardiographic analyses of the above relationship give the following numerical values:

TABLE 3

\begin{tabular}{|c|c|c|c|c|c|c|c|c|c|c|c|}
\hline Time $(\mathrm{min}$. & Control & 1 & 2 & 3 & 5 & 10 & 15 & 20 & 25 & 30 & 35 \\
\hline Nicotine $6.5 \mathrm{mg} / \mathrm{kg}$ & 31 & 23 & 18 & 14 & 9 & 3 & 0 & & & & \\
\hline $\begin{array}{l}\text { TER. } 1000 \mathrm{mg} / \mathrm{kg} \\
\text { Nicot. } 6.5 \mathrm{mg} / \mathrm{kg}\end{array}$ & 29 & 28 & 22 & 20 & 27 & 28 & 28 & 28 & 28 & 29 & \\
\hline
\end{tabular}


Fig. 9

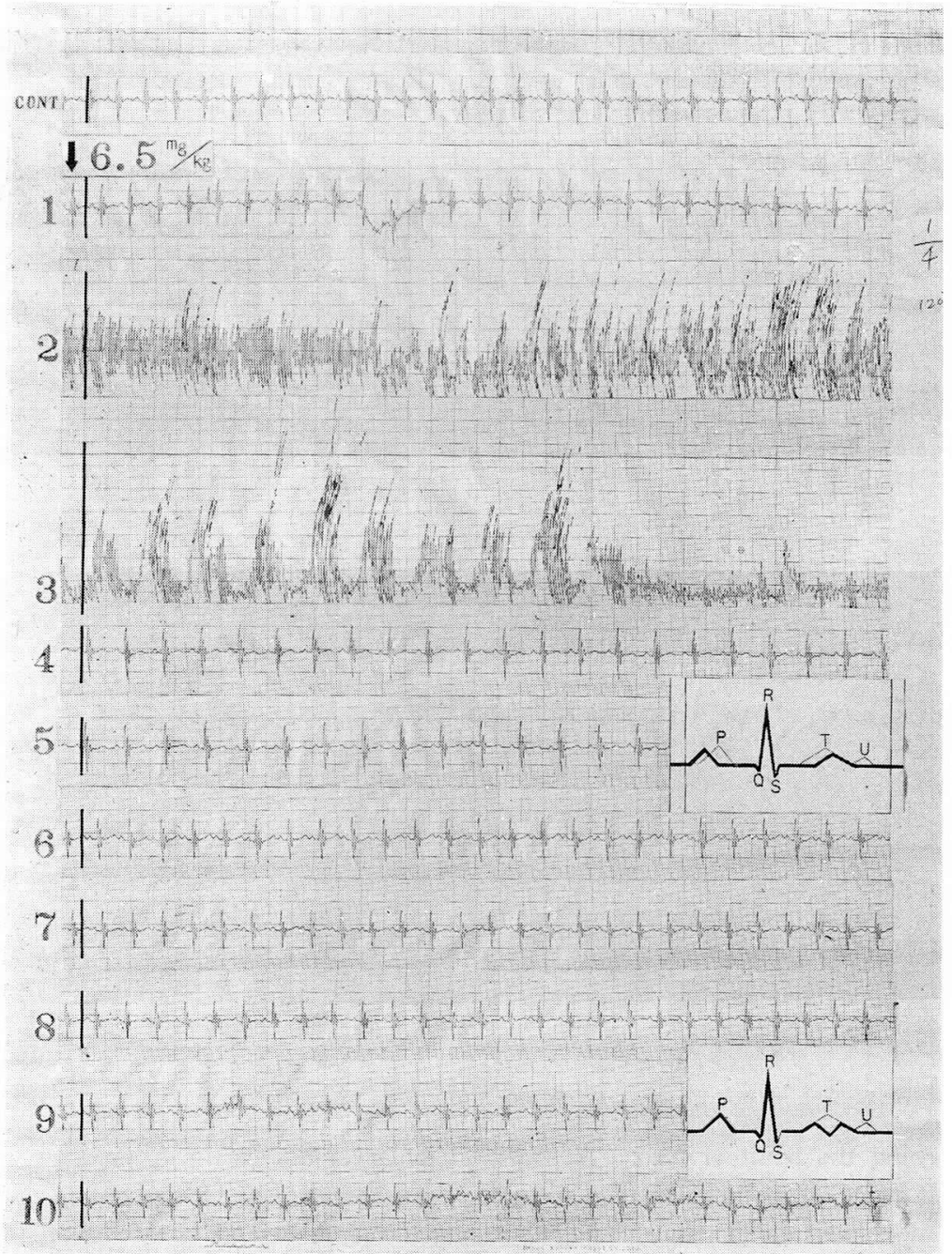

\section{G. Antitoxic Action of TERPIDAN upon Acute Nicotinism}

When pure nicotine diluted with physiological salt solution was injected into the caudal vein of mice, $0.01 \%$ of nicotine solution per body weight of $15 \mathrm{~g}$ needed $0.155 \mathrm{cc}$ to consitute LD 100. So as to obtain a relatively stable toxicity, the solution was left for about one hour before the use. $1000 \mathrm{mg} / \mathrm{kg}$ TERPIDAN was orally administered to the experimental mice and when LD 100 nicotine solution was injected into the caudal vein, the rate of survival was anywhere from 90-100\%. As the toxicity of nicotine acts instantly, the death occurs immediately after its administration.

H. Antitoxic Action of TERPIDAN upon Chronic Nicotinism

For the experimental purposes under this heading, use was made of one-month 
Fig. 10

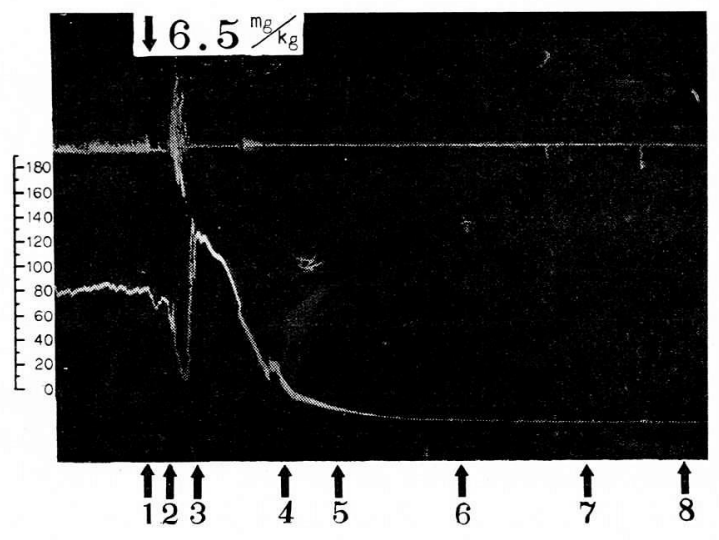

Fig. 11

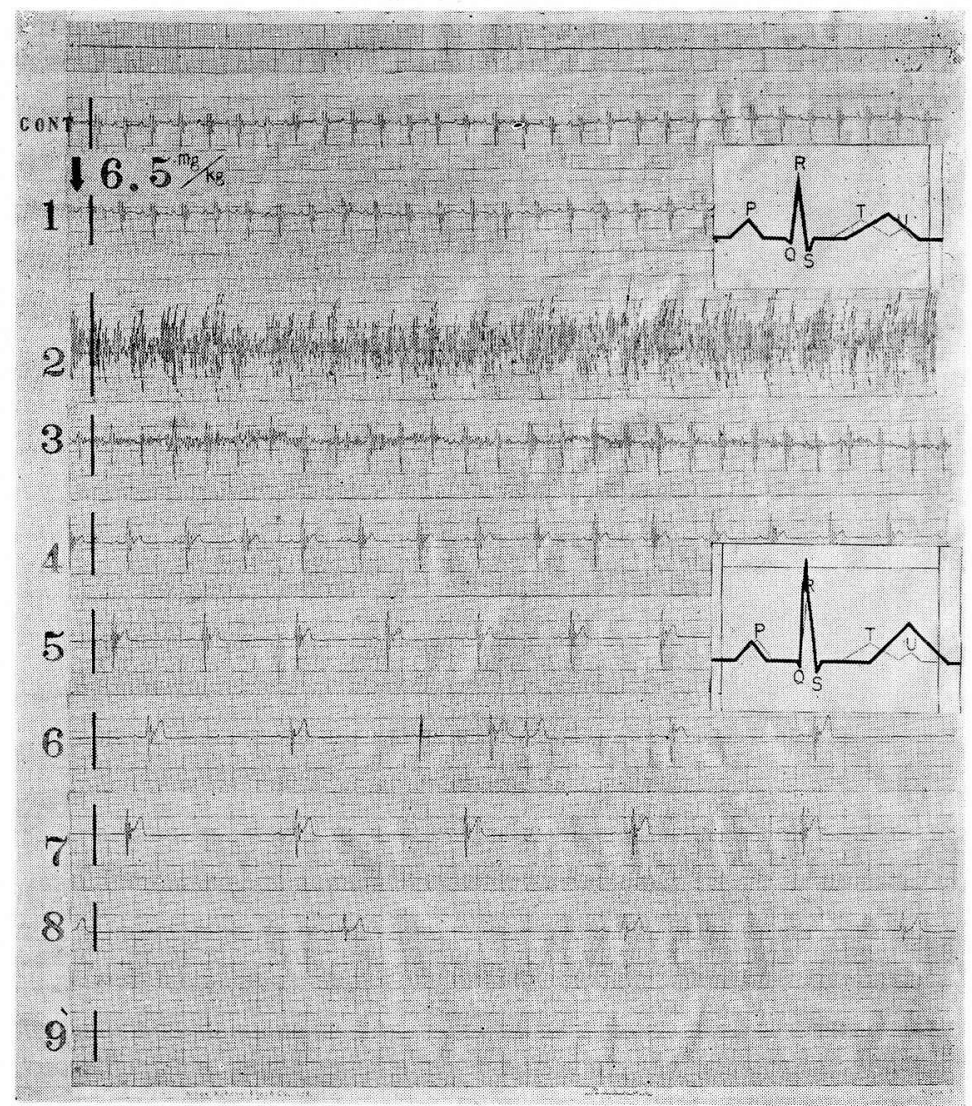


mice with the weight range of 50-60 g and regardles of sex distinction they were divided into the following four groups.

1) Control group (non-treatment)

2) TERPIDAN group (a daily administration of $25 \mathrm{mg} / \mathrm{kg}$ TERPIDAN)

3) Nicotine group (a daily subcutaneous injection of $0.02 \mathrm{mg} / \mathrm{kg}$ nicotine)

4) Mixed group (a daily administration of both $25 \mathrm{mg} / \mathrm{kg}$ TERPIDAN and $0.02 \mathrm{mg} / \mathrm{kg}$ nicotine)

The animals chosen were fed with the solid Oriental food and their weight changes were measured daily at the fixed time. Observations were kept up regarding their growth over a period of 8 weeks.

In contrast to control, the nicotine group showed growth inhibition after 10 days with the tendency getting worse proportionally to the passage of time. However, mice in the mixed group showed normal pace of growtn. The TERPIDAN group showed somewhat better growth than control. From this it is known that a prolonged administration of TERPIDAN (2 months) is harmless and it definitely possesses antitoxic action upon chronic nicotinism (Fig. 12).

Fig. 12

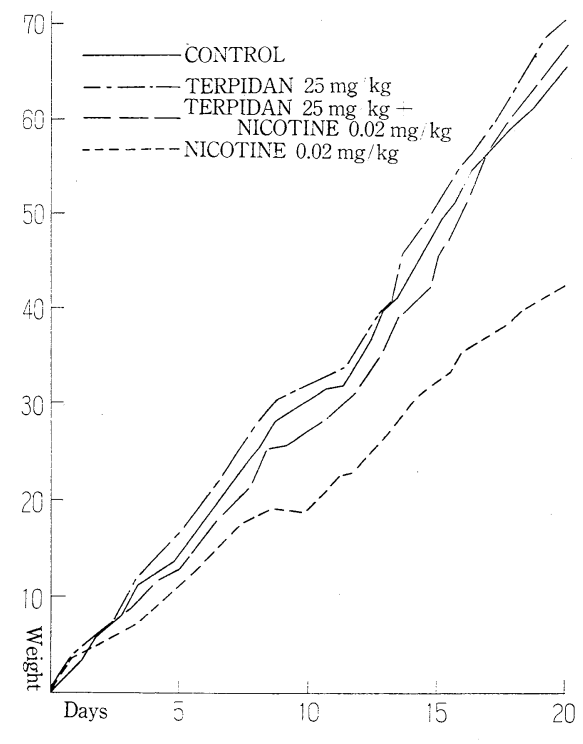

\section{Comparison of TERPIDAN with Lobeline Hydrochloride}

The results obtained so far show that although TERPIDAN itself has no effect to promote repiratory movement, it comes to possess it when used in conjunction with $6.5 \mathrm{mg} / \mathrm{kg}$ nicotine. We inferred this phenomenon to rise from the effect of nicotine upon the central nerves. In order to establish the fact of TERPIDAN poessessing respiratory promotion effect in conjunction with other drug of the same virtue, we selected lobeline hydrochloride for this purpose. 
The use of lobeline hydrochloride gives forth the following data:

$\begin{array}{ccl}\text { Quantity } & \text { Respiratory movement } & \text { Blood pressure } \\ 0.15 \mathrm{mg} / \mathrm{kg} & \text { No changes } & \text { Slight decrease } \\ 0.3 \mathrm{mg} / \mathrm{kg} & \text { Promotion } & \text { Decrease by } 30 \mathrm{~mm} \\ 0.6 \mathrm{mg} / \mathrm{kg} & \text { Inhibition } & \text { Decrease by } 20 \mathrm{~mm} \\ & & \text { (lasting character) }\end{array}$

However, when $250 \mathrm{mg} / \mathrm{kg}$ of TERPIDAN was used as pre-medication followed by an injection $0.15 \mathrm{mg} / \mathrm{kg}$ lobeline hydrochloride, the respiratory promotive effect of the latter was completely checked. From these findings we may conclude that TERPIDAN does not act in conjunction with lobeline hydrochloride and our previous inference proved groundless. In short, the respiratory promotive effect of nicotine is peculiar to itself and TERPIDAN has nothing to do with it.

Fig. 13
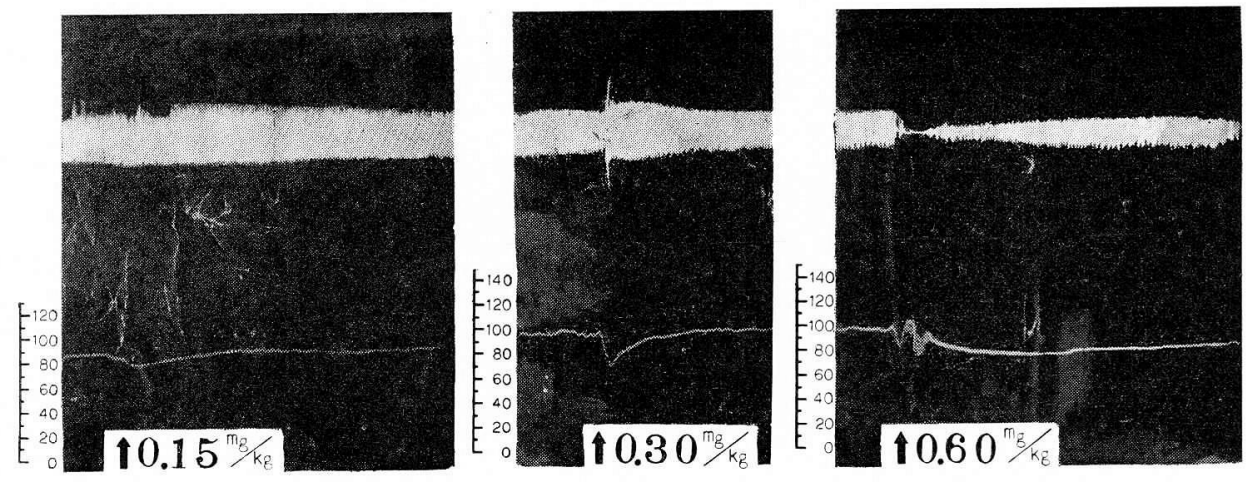

Fig. 14

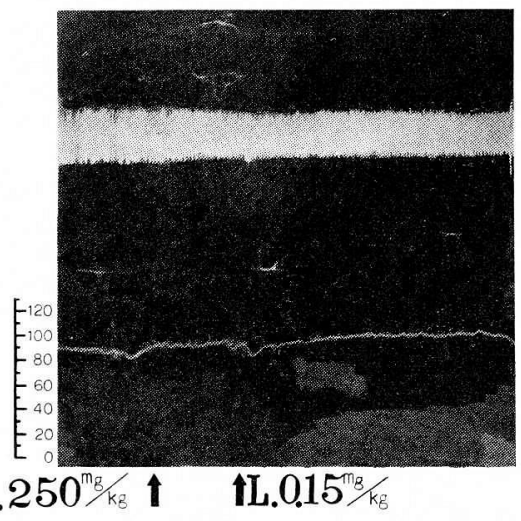

\section{J. Convulsive Effect of Morphine and TERPIDAN}

It is a known fact that when a certain amount of morphine is administered to mice they give forth an S-letter convulsion on the tail and it is by no means confined to morphine alone, other alkaloids sharing the same effect. 
We tried to find out possible relation between this convulsive movement and effect of TERPIDAN. Mice weighing around $17 \mathrm{~g}$ were divided into two groups regardless of sex distinction. One group was injected $10 \%$ solution of opium into the caudal vein, while the other was treated with $1.2 \mathrm{mg} / \mathrm{kg}$ TERPIDAN and then injected with same opium solution half an hour later Thus measurements were taken from the start of convulsion to the end of it.

Table 4 gives the result in the tabular form. These figures are ample evidence that the pre-medication of TERPIDAN inhibits the said convulsion to a great extent.

TABLE 4

\begin{tabular}{c|c|c|c|c}
\hline $\begin{array}{c}\text { Mice weight } \\
(\mathrm{g})\end{array}$ & $\begin{array}{c}\text { TER. dosage } \\
\mathrm{g} / \mathrm{kg}\end{array}$ & $\begin{array}{c}\text { Opium dosage } \\
\mathrm{g} / \mathrm{kg}\end{array}$ & $\begin{array}{c}\text { Time till convulsive } \\
\text { movement cccurs }\end{array}$ & $\begin{array}{c}\text { Time from the start } \\
\text { to the end of reactions }\end{array}$ \\
\cline { 1 - 2 } 18 & 1.2 & 0.12 & $17 \mathrm{~min}$. & $26 \mathrm{~min}$. \\
18 & 1.2 & 0.12 & $18 \mathrm{~min}$. & $20 \mathrm{~min}$. \\
17 & 1.2 & 0.12 & - & - \\
17 & 1.2 & 0.12 & - & - \\
15 & 1.2 & 0.12 & - & $65 \mathrm{~min}$. \\
18 & & 0.12 & $6 \mathrm{~min}$. & $62 \mathrm{~min}$. \\
17 & & 0.12 & $7 \mathrm{~min}$. & $40 \mathrm{~min}$. \\
17 & & 0.12 & $9 \mathrm{~min}$. & $45 \mathrm{~min}$. \\
15 & & 0.12 & $8 \mathrm{~min}$. & $37 \mathrm{~min}$. \\
\hline \hline
\end{tabular}

- indicates no reactions

\section{Conclusions}

As a result of various experiments referred to in the foregoing section, we have established the fact that TERPIDAN which is a newly developed antidote possesses antitoxic actions upon nicotine and morphine.

The salient findings discussed are as follows.

1) In terms of the experimental rabbit TD 50 of this drug corresponds to $1.7 \mathrm{~g} / \mathrm{kg}$. A dosage of $1.0 \mathrm{~g} / \mathrm{kg}$ shows no toxicity. Of the Japanese domestic cigarettes, IKOI is found to be most potent in toxicity and NIKKO to be weakest.

2) An injection of $500 \mathrm{mg} / \mathrm{kg}$ TERPIDAN into the auricular vein has given rise to no changes in electrocardiograph and ophthal pressure.

3) Effects of $6 \mathrm{mg} / \mathrm{kg}$ nicotine to which TERPIDAN was half an hour previously administered were greatly checked, registering no appreciable changes in electrocardiograph and ophthal pressure. The recovery could be effected in twenty to thirty minutes.

4) The previous administration of TERPIDAN is useful in inhibiting effects of nicotine as much as $6.5 \mathrm{mg} / \mathrm{kg}$. With this amount, the recovery could be effected in half an hour.

The relation between respiratory movement and blood pressure brought about by nicotine has a behavior reverse to that of adrenalin.

5) The administration of TERPIDAN is found to show high antitoxic action upon 
an acute nicotinism of mice.

6) TERPIDAN acts favorably upon mice and checks a decrease in weight. Thus it enables the nicotinic mice to grow as well as control mice. No harm has been observed for its administration of long duration.

7) This drug has a slight inhibitory effect on lobeline hydrochloride which promotes the respiratory movement.

8) This drug remarkably inhibits the convulsive movement peculiar to morphinism.

The authors are being engaged in their clinical application of TERPIDAN and hope that they may have an opportunity to make public their result in the near future.

\section{References}

1) Yamamoto, I., Kurokochi, H. and TAKeuchi, M. : Inquiry into Antitoxic Action of Nicotine in Rabbits by Means of Silicon Molybdenum Acid, Folia pharmacol. japan., 51 (1) $60(1955)$

2) TAKEUCHI, M: Study on the Nicotinic Metabolism with Reference to its Changes in Liver Extract, Folia pharmacol. japon., 51 (1) 62(1955)

3) Yamamoto, I., Tsujimura, Y. and Tsujimoto, A. : On the Bodily Distribution of Nicotine, Folia pharmacol. japon., 51 (4) 500 (1955)

5) MAEDA, T. : Action Behavior of Nicotine upon Broncheal Muscles extracted from Guinea Pigs and Rabbits and Influences of Autonomic Nerve Poison, Folia pharmacol. japon., 51 (4) $506(1955)$

6) OtoRir, T. and Mryazawa, H. : Study on the Decomposition of Atropin and Scopolamine in the Body, Folia pharmacol. japon., 51 (5) 1391 (1955)

7) Takadama, M. : Studies on the Action of Nicotine, Part II, Folia pharmacol. japon., 51 (5) $142(1955)$

8) Murotsuka, H. : Studies on the Action of Nicotine, Part VI, (Influences of Nicotine upon $\mathrm{B}_{1}$ Metabolism), Folia pharmacol. japon., 52 (1) 561 (1955)

9) Hakusuka, Y.: Studies on the Action of Nicotine, Part VII, (Influences of Nicotine upon Iodine Elimination), Folia phamacol. japon., 52 (1) 56 (1956)

10) Yamamoto, I., Tsujimoto, A., Yoshimura, K., Kitamura, T. and Iwata, H. : Study on the Metabolism of Nicotine, Folia pharmacol. japon., 51 (5) 143 (1955)

11) KIwAKI, T.: Influences of Nicotine upon the Fetus of Hens, Folia pharmacol. japon., 52 (2) 186 (1956)

12) TAKaSAKi, K. : Mechanism of Halt of Repiration by Nicotine, Folia pharmacol. japon., 52 (2) 92 (1956)

13) SEkiYA, Y.: Observations on the Occurrence of Edemas in Hen Fetus through Nicotine Administration, Folia pharmacol. japon., 52 (3) 370 (1956)

14) Sekiya, Y. : On Relationship between the Nicotinic Edema and Diuretic of Purine Derivative, Folia pharmacol. japon., 52 (3) 398 (1956)

15) The Tabacco Growers Asso., : Tabacco Reader, 1949.

16) Japan Monopoly Corporation: The Official Analytical Method of Tabacco, 1959.

17) Anti-toxic Effects of Vitamins B on Nicotine in the Experimental and Clincal Lights, Ochanomizu Medical Journal, 8 : 149 (1960)

18) Reports published by Japan Monopoly Corporation, No. 60, 1957.

19) Yamamoto, I. : Nicotinic Metabolism, contributed to Science to Life, 6 (4), 1955.

20) Yamamoto, I. : Nicotinic Metabolism and Anti-toxic Effects, a lecture delivered before the 7th Congress of Japan Physiological Science, 1957. 